\title{
Carbon Assimilation and Carbohydrate Metabolism of 'Concord' Grape (Vitis labrusca L.) Leaves in Response to Nitrogen Supply
}

\author{
Li-Song Chen ${ }^{1}$ and Lailiang Cheng ${ }^{2}$ \\ Department of Horticulture, Cornell University, Ithaca, NY14853
}

\begin{abstract}
ADDITIONAL INDEX wORDS. ADP-glucose pyrophosphorylase, fructose-1,6-bisphosphatase, metabolites, NADP-glyceraldehyde-3-phosphate dehydrogenase, phosphoribulokinase, ribulose-1,5-bisphosphate carboxylase/oxygenase, sucrose phosphate synthase
\end{abstract}

\begin{abstract}
Aвstract. One-year-old grapevines (Vitis labrusca L. 'Concord') were supplied twice weekly for 5 weeks with $0,5,10,15$, or $20 \mathrm{~mm}$ nitrogen $(\mathrm{N})$ in a modified Hoagland's solution to generate a wide range of leaf $\mathrm{N}$ status. Both light-saturated $\mathrm{CO}_{2}$ assimilation at ambient $\mathrm{CO}_{2}$ and at saturating $\mathrm{CO}_{2}$ increased curvilinearly as leaf $\mathrm{N}$ increased. Although stomatal conductance showed a similar response to leaf $\mathrm{N}$ as $\mathrm{CO}_{2}$ assimilation, calculated intercellular $\mathrm{CO}_{2}$ concentrations decreased. On a leaf area basis, activities of key enzymes in the Calvin cycle, ribulose-1,5-bisphosphate carboxylase/ oxygenase (Rubisco), NADP-glyceraldehyde-3-phosphate dehydrogenase (GAPDH), phosphoribulokinase (PRK), and key enzymes in sucrose and starch synthesis, fructose-1,6-bisphosphatase (FBPase), sucrose phosphate synthase (SPS), and ADP-glucose pyrophosphorylase (AGPase), increased linearly with increasing leaf $\mathbf{N}$ content. When expressed on a leaf $\mathbf{N}$ basis, activities of the Calvin cycle enzymes increased with increasing leaf $\mathbf{N}$, whereas activities of FBPase, SPS, and AGPase did not show significant change. As leaf N increased, concentrations of glucose-6-phosphate (G6P), fructose-6-phosphate (F6P), and 3-phosphoglycerate (PGA) increased curvilinearly. The ratio of G6P/F6P remained unchanged over the leaf $N$ range except for a significant drop at the lowest leaf $N$. Concentrations of glucose, fructose, and sucrose at dusk increased linearly with increasing leaf $\mathrm{N}$, and there was no difference between predawn and dusk measurements. As leaf $\mathrm{N}$ increased, starch concentration increased linearly at dusk, but decreased linearly at predawn. The calculated carbon export from starch degradation during the night increased with increasing leaf $\mathrm{N}$. These results showed that 1) grapes leaves accumulated less soluble carbohydrates under N-limitation; 2) the elevated starch level in low $\mathrm{N}$ leaves at predawn was the result of the reduced carbon export from starch degradation during the night; and 3 ) the reduced capacity of $\mathrm{CO}_{2}$ assimilation in low $\mathrm{N}$ leaves was caused by the coordinated decreases in the activities of key enzymes involved in $\mathrm{CO}_{2}$ assimilation as a result of direct $\mathrm{N}$ limitation, not by the indirect feedback repression of $\mathrm{CO}_{2}$ assimilation via sugar accumulation.
\end{abstract}

Photosynthesis depends on the function and coordination of many proteins and enzymes, which account for the majority of nitrogen $(\mathrm{N})$ in leaves. Therefore, the rate of $\mathrm{CO}_{2}$ assimilation has been closely related to leaf $\mathrm{N}$ status (Evans, 1989). N limitation leads to the reduction in the activities of enzymes involved in photosynthesis, and consequently a decrease in the rate of $\mathrm{CO}_{2}$ assimilation (Cheng and Fuchigami, 2000; Evans, 1989; Makino et al., 1994; Robinson and Baysdorfer, 1985). There are two overall mechanisms by which $\mathrm{CO}_{2}$ assimilation is lowered by $\mathrm{N}$ limitation. Low $\mathrm{N}$ supply can directly reduce the amount of proteins and enzymes that are involved in $\mathrm{CO}_{2}$ assimilation. Alternatively, because low $\mathrm{N}$ supply also affects the sink activity to utilize the assimilated carbon, it is possible that $\mathrm{N}$ limitation reduces sink demand for carbon more than the source capacity to supply carbon, leading to accumulation of carbohydrates in source leaves, which, in turn, down-regulates $\mathrm{CO}_{2}$ assimilation.

Sugar repression of photosynthesis has been generally accepted as a feedback mechanism to ensure that the carbon flow is balanced between the source and the sink (Jang and Sheen, 1994; Paul and Pellny, 2003). However, determining whether this mechanism operates in intact plants under the conditions of interest requires demonstrating accumulation of carbohydrates and establishing a causal relationship between accumulation of carbohydrates and

This work was supported in part by the USDA Viticulture Consortium Program and New York Wine and Grape Foundation.

'Permanent address: Department of Horticulture, Fujian Agriculture and Forestry University, Fuzhou 350002, P.R. China.

${ }^{2}$ Corresponding author; email LC89@Cornell.edu. repression of $\mathrm{CO}_{2}$ assimilation. In the case of $\mathrm{N}$ limitation, accumulation of carbohydrates was often observed in leaves (Geiger et al., 1999; Logan et al., 1999; Paul and Driscoll, 1997; Rufty et al., 1988). Reducing $\mathrm{N}$ supply caused a gradual decrease of leaf ribulose-1,5-bisphosphate carboxylase/oxygenase (Rubisco, EC4.1.1.39) protein and $\mathrm{CO}_{2}$ assimilation in tobacco (Paul and Driscoll,1997). This was accompanied by an increase in hexoses, sucrose, and starch. Altering the source to sink ratio by shading some of the leaves prevented the increase in accumulation of carbohydrates and the decrease in $\mathrm{CO}_{2}$ assimilation under $\mathrm{N}$ limitation. All these responses are consistent with sugar repression of photosynthesis. However, carbohydrates do not always accumulate in leaves of plants under $\mathrm{N}$ limitation. Glucose and starch levels in bean (Phaseolus vulgaris L.) leaves were about 50\% lower under low $\mathrm{N}$ supply, compared with those under high $\mathrm{N}$ supply, at both ambient and elevated $\mathrm{CO}_{2}$ (Jifon and Wolfe, 2002). Less accumulation of nonstructural carbohydrates at low compared to high $\mathrm{N}$ supply was also found in leaves of bean (Radoglou and Jarvis, 1992) and Dactylis glomerata (Harmens et al., 2000). In addition, in sugar feeding and elevated $\mathrm{CO}_{2}$ experiments, the suppression of photosynthetic genes by elevated levels of carbohydrates was only observed under low $\mathrm{N}$ supply, not in high $\mathrm{N}$ supply. This suggests that $\mathrm{N}$ status or the interaction between $\mathrm{N}$ and carbohydrates plays a more important role than carbohydrate level itself (Geiger et al., 1999; Martin et al., 2002; Nielsen et al., 1998). Therefore, it is still equivocal whether repression of photosynthesis via accumulation of carbohydrates plays a key role in determining the rate of $\mathrm{CO}_{2}$ assimilation under $\mathrm{N}$ limitation. 
The objectives of this study were 1) to determine the effect of $\mathrm{N}$ supply on $\mathrm{CO}_{2}$ assimilation and activities of key enzymes in the Calvin cycle and end-product synthesis of grape leaves; 2) to distinguish, if possible, the mechanism of direct $\mathrm{N}$ limitation on $\mathrm{CO}_{2}$ assimilation with an indirect mechanism, or feedback suppression via carbohydrate accumulation, by measuring metabolite and carbohydrate levels in response to $\mathrm{N}$ supply.

\section{Materials and Methods}

Plant culture and N treatments. Own-rooted 1-year-old grapevines (Vitis labrusca 'Concord') were pruned to 2 nodes and transplanted into 7.6-L plastic pots containing sand before budbreak. Plants were grown outdoors at Cornell Experimental Orchards in Ithaca, N.Y. ( $\left.42^{\circ} 26^{\prime} \mathrm{N}, 7^{\circ} 29^{\prime} \mathrm{W}\right)$. At budbreak in mid-May, extra shoots were removed and a single vegetative shoot was allowed to grow on each plant. Beginning from the third week after budbreak, each plant was supplied once a week with $500 \mathrm{~mL}$ of $10 \mathrm{~mm} \mathrm{~N}$, using Peters $20 \mathrm{~N}-10 \mathrm{P}_{2} \mathrm{O}_{5}-20 \mathrm{~K}_{2} \mathrm{O}$ water soluble fertilizer with micronutrients (Scotts-Sierra Horticultural Products, Marysville, Ohio). When new shoots were $\approx 30 \mathrm{~cm}$ long, uniform plants were selected and randomly assigned to one of the following five $\mathrm{N}$ treatments. Each plant was supplied twice weekly with $500 \mathrm{~mL}$ of a modified Hoagland's nutrient solution at an $\mathrm{N}$ concentration of $0,5,10,15$, or $20 \mathrm{~mm}$ (from $\mathrm{NH}_{4} \mathrm{NO}_{3}$ ) (Cheng and Fuchigami, 2000). There were four replications per $\mathrm{N}$ treatment with three sample plants each in a completely randomized design. After 5 weeks of $\mathrm{N}$ treatments, recent fully expanded leaves were chosen for measuring gas exchange, chlorophyll (Chl), N, enzyme activities, metabolites, and nonstructural carbohydrates.

Gas exchange measurements. Measurements (one leaf per replicate) were made via a CIRAS-1 portable photosynthesis system (PP systems, Herts, U.K.) at ambient $\mathrm{CO}_{2}\left(360 \mu \mathrm{mol} \cdot \mathrm{mol}^{-1}\right)$ and saturating $\mathrm{CO}_{2}\left(1350 \mu \mathrm{mol} \cdot \mathrm{mol}^{-1}\right)$ under natural photon flux density (PFD) of $1800 \pm 50 \mu \mathrm{mol} \cdot \mathrm{m}^{-2} \cdot \mathrm{s}^{-1}$ from 10:30 AM to 12: $00 \mathrm{PM}$ on a clear day. The saturating $\mathrm{CO}_{2}$ concentration (1350 $\left.\mu \mathrm{mol} \cdot \mathrm{mol}^{-1}\right)$ was determined beforehand by measuring responses of $\mathrm{CO}_{2}$ assimilation to $\mathrm{CO}_{2}$ concentration (data not included). Leaf temperature and ambient vapor pressure were $28.0 \pm 1.0^{\circ} \mathrm{C}$ and $1.9 \pm 0.1 \mathrm{kPa}$ during all the measurements.

Extraction AND ASSAY OF ENZYMEs. Leaf discs $\left(1 \mathrm{~cm}^{2}\right.$ in size) were taken from the same leaves used for gas exchange measurements at noon at a PFD of $1800 \mu \mathrm{mol} \cdot \mathrm{m}^{-2} \cdot \mathrm{s}^{-1}$. Two leaf discs were used immediately for Rubisco extraction. For all the other enzymes, leaf discs were frozen in liquid $\mathrm{N}_{2}$ and stored at $-80^{\circ} \mathrm{C}$ until analysis.

Rubisco was extracted and assayed according to Cheng and Fuchigami (2000). The only modification was that $5 \mathrm{~mm}$ dithiothreitol (DTT) and $0.4 \%(\mathrm{v} / \mathrm{v})$ Triton X-100 were used in place of mercaptoethanol and Tween- 80 in the extraction buffer. Total Rubisco activity was measured after incubating the leaf extract in the assay solution for $15 \mathrm{~min}$ at room temperature.

NADP-glyceraldehyde-3-phosphate dehydrogenase(GAPDH, EC1.2.1.12), phosphoribulokinase (PRK, EC2.7.1.19), fructose1,6-bisphosphatase (FBPase, EC3.1.3.11), and sucrose phosphate synthase (SPS, EC2.4.1.14) were extracted from three frozen leaf discs. The leaf discs were ground with a precooled mortar and pestle in $1.5 \mathrm{~mL}$ extraction buffer containing $50 \mathrm{~mm}$ Hepes-KOH (pH7.5), $10 \mathrm{~mm} \mathrm{MgCl}_{2}, 2 \mathrm{~mm}$ ethylenediaminetetraacetic acid (EDTA), 10 mm DTT, 1\%(v/v) Triton X-100, 5\% (w/v) insoluble polyvinylpolypyrrolidone (PVPP), $1 \%(\mathrm{w} / \mathrm{v})$ bovine serum albu- min (BSA), $10 \%$ (v/v) glycerol, and 0.5 mm phenylmethylsulfonyl fluoride (PMSF). The extract was centrifuged at 13,000 $g_{n}$ for 5 min in an Eppendorf microcentrifuge, and the supernatant was used immediately for enzyme activity assay.

GAPDH activity was determined in a mixture $(1 \mathrm{~mL})$ of 100 mM Tricine-KOH (pH8.0), 4 mm 3-phosphoglycerate (PGA), 5 mм ATP, $10 \mathrm{~mm} \mathrm{MgCl}_{2}, 0.2 \mathrm{~mm}$ NADPH, and 20 units 3-phosphoglyceric phosphokinase (PCK, EC2.7.2.3). The reaction was initiated by adding the enzyme extract (Leegood, 1990).

PRK activity was assayed in a mixture $(1 \mathrm{~mL})$ of $100 \mathrm{~mm}$ Tricine- $\mathrm{KOH}$ (pH8.0), $0.5 \mathrm{~mm}$ ribose 5-phosphate (R5P), $1 \mathrm{~mm}$ ATP, $10 \mathrm{~mm} \mathrm{MgCl}_{2}, 5 \mathrm{~mm}$ phosphenolpyruvate (PEP), $0.4 \mathrm{~mm}$ $\mathrm{NADH}, 7$ units pyruvate kinase (EC2.4.1.40), 10 units lactate dehydrogenase (LDH, EC1.1.1.27), and 1 unit R5P isomerase (EC5.1.3.4). The reaction was initiated by adding the enzyme extract (Leegood, 1990).

FBPase was assayed spectrophotometrically by measuring fructose-1,6-bisphosphate (FBP) dependent fructose-6-phosphate (F6P) formation (Leegood, 1990).

SPS was assayed according to Grof et al. (1998) with minor modifications. Leaf extract $(60 \mu \mathrm{L})$ was incubated for $15 \mathrm{~min}$ at $30{ }^{\circ} \mathrm{C}$ with $100 \mathrm{~mm}$ Hepes-KOH (pH7.5), $100 \mathrm{~mm} \mathrm{KCl,} 6 \mathrm{~mm}$ EDTA, 30 mм uridine 5'-diphosphoglucose (UDPG), 10 mм F6P, and $40 \mathrm{~mm}$ glucose-6-phosphate (G6P) in a total volume of 100 $\mu \mathrm{L}$. At the end of the $15 \mathrm{~min}$ incubation period, the reaction was stopped by adding $100 \mu \mathrm{L}$ ice-cold $1.2 \mathrm{~mm} \mathrm{HClO}_{4}$ and held on ice for another $15 \mathrm{~min}$. The reaction mixture was neutralized by adding $60 \mu \mathrm{L}$ of $2 \mathrm{~mm} \mathrm{KHCO}_{3}$, held on ice for $15 \mathrm{~min}$, and then centrifuged at $13,000 g_{\mathrm{n}}$ for $1 \mathrm{~min}$. An aliquot $(130 \mu \mathrm{L})$ of the supernatant was assayed for uridine 5' -diphosphate (UDP) by coupling to oxidation of NADH with LDH and pyruvate kinase. The reaction mixture $(1 \mathrm{~mL})$ contained $50 \mathrm{~mm}$ Hepes- $\mathrm{KOH}(\mathrm{pH} 7.5)$, $200 \mathrm{~mm} \mathrm{KCl,} 40$ mм $\mathrm{MgCl}_{2}$, 0.2 mм NADH, 2 mм PEP, 17 units LDH, and 10 units Pyr kinase. Controls without F6P and G6P were carried through for all the samples.

ADP-glucose pyrophosphorylase (AGPase, EC2.7.7.27) was extracted according to Kerr et al. (1984) with some modifications. Three frozen leaf discs (total of $3 \mathrm{~cm}^{2}$ ) were ground with a pre-cooled mortar and pestle in $1.5 \mathrm{~mL}$ extract buffer containing $50 \mathrm{~mm}$ Hepes- $\mathrm{NaOH}$ (pH 7.5), 5 mм $\mathrm{MgCl}_{2}, 1$ mм EDTA, $2 \mathrm{~mm}$ reduced glutathione $(\mathrm{GSH}), 2 \%(\mathrm{w} / \mathrm{v})$ polyethylene glycol-20000 (PEG-20), 1\%(w/v) BSA, $0.4 \%(\mathrm{v} / \mathrm{v})$ Triton X-100, and 5\% (w/v) insoluble PVPP. The extract was then centrifuged at $13,000 g_{\mathrm{n}}$ for 5 min in an Eppendorf microcentrifuge, and the supernatant was used immediately for AGPase activity measurement. The enzyme activity was assayed by measuring pyrophosphate $\left(\mathrm{PP}_{\mathrm{i}}\right)$ dependent glucose-1-phosphate (G1P) formation using a continuous spectrophotometric assay (Smith et al., 1989). The assay mixture (1 mL) contained $50 \mathrm{~mm}$ Hepes-KOH (pH 8.0), $1 \mathrm{~mm}$ adenosine 5'-diphosphoglucose (ADPG), $5 \mathrm{~mm} \mathrm{MgCl}_{2}, 0.6 \mathrm{~mm}$ NAD, $1.5 \mathrm{~mm} \mathrm{PP}$, 3 mM PGA, 2 units G6P dehydrogenase (G6PDH, EC1.1.1.49, NAD-linked, from Leuconostoc mesenteroides), 2 units phosphoglucomutase (EC5.4.2.2), and $20 \mu \mathrm{L}$ of extract. The reaction was initiated by adding $\mathrm{PP}_{\mathrm{i}}$.

EXTRACTION AND DETERMINATION OF METABOLITES. Metabolites were extracted according to Chen et al. (2002) with some modifications. Briefly, $40-\mathrm{cm}^{2}$ leaf tissues were taken at noon under full sun (PFD of $1800 \mu \mathrm{mol} \cdot \mathrm{m}^{-2} \cdot \mathrm{s}^{-1}$ ), frozen in liquid $\mathrm{N}_{2}$ and stored at $-80{ }^{\circ} \mathrm{C}$ until analysis. The frozen leaf tissues were ground in liquid $\mathrm{N}_{2}$ with a mortar and pestle, and $4 \mathrm{~mL}$ ice-cold $5 \%(\mathrm{w} / \mathrm{v})$ trichloroacetic acid (TCA) that contained $200 \mathrm{mg}$ insoluble PVPP was added to the powder and gently pulverized. The mixture was 
allowed to thaw slowly on ice. The resulting suspension was kept on ice for 30 min to allow insoluble PVPP to bind phenolic compounds, then centrifuged for $10 \mathrm{~min}$ at 20,000 $g_{\mathrm{n}}$. Three $\mathrm{mL}$ supernatant was mixed with $30 \mathrm{mg}$ charcoal (activated, washed with $\mathrm{HCl}$ ). The mixture was kept on ice, and vortexed at least three times during a 15 min period. The charcoal was precipitated by $10 \mathrm{~min}$ centrifugation at $20,000 \mathrm{~g}_{\mathrm{n}}$. The supernatant was used for the measuring G6P, F6P, and PGA.

G6P and F6P were determined spectrophotometrically (Chen et al., 2002). PGA was measured in a reaction mixture $(1 \mathrm{~mL})$ containing 40 mм Hepes-KOH (pH 7.5), 0.2 mм NADH, 5 mм ATP, $5 \mathrm{~mm}$ phosphocreatine, 10 units creatine phosphokinase (EC2.7.3.2), 5 units GAPDH, 5 units PCK, and an aliquot of extract. PGA concentration was determined by the difference in absorbance at $340 \mathrm{~nm}$ before and after the addition of PCK (Usuda, 1985). The recoveries of G6P, F6P, and PGA, when added as internal standards to the samples, were $90 \%$ to $102 \%$ in all cases.

EXTRACTION AND MEASUREMENT OF LEAF NONSTRUCTURAL CARBOHYDRATES. Three leaf discs (total of $3 \mathrm{~cm}^{2}$ ) were taken at dusk
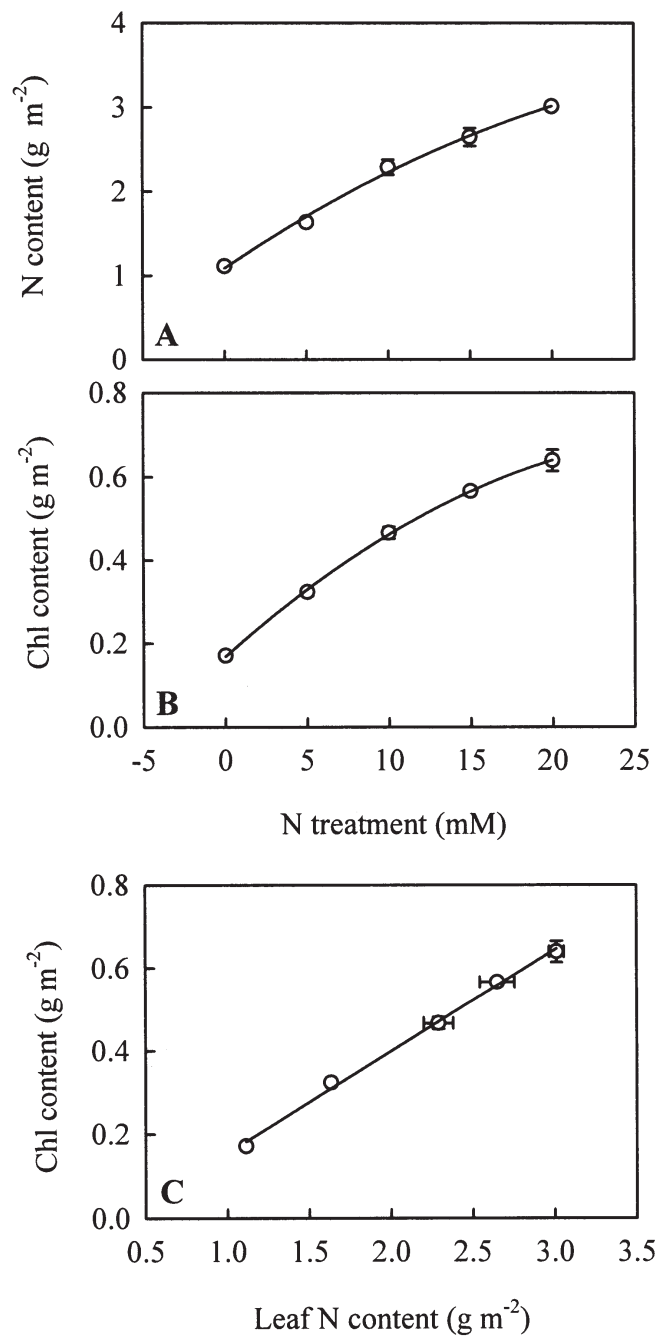

Fig. 1. Effects of nitrogen (N) supply on leaf N (A) and chlorophyll (Chl ) (B) contents, and the relationship between leaf $\mathrm{N}$ content and $\mathrm{Chl}$ content $(\mathrm{C})$ in grape leaves. Each point is mean \pm standard error of the dependent variables of four replications (A and $\mathbf{B}$ ), or for the leaf $\mathrm{N}$ (horizontal) and $\mathrm{Chl}$ content (vertical) of four replications $(\mathbf{C})$. If bar is not apparent, the standard error was smaller than the point marker. Regression equations: $(\mathbf{A}), \mathrm{y}=-0.0018 x^{2}+0.1314 x+$ $1.0887\left(r^{2}=0.996, P<0.01\right) ;(\mathrm{B}), \mathrm{y}=-0.0006 x^{2}+0.035 x+0.1687\left(r^{2}=0.999\right.$, $P<0.01) ;(\mathrm{C}), \mathrm{y}=0.2449 x-0.0911\left(r^{2}=0.997, P<0.01\right)$. (end of the approximately 15-h light period) and at predawn (end of the approximately 9 -hour dark period) from the same leaf (one leaf per replicate), frozen in liquid $\mathrm{N}_{2}$ and stored at $-80^{\circ} \mathrm{C}$ until analysis. Soluble sugars (sucrose, glucose, and fructose) were extracted with $80 \%$ ethanol at $80{ }^{\circ} \mathrm{C}$ three times $(4 \mathrm{~mL}$ each for $30 \mathrm{~min})$. After centrifugation, the supernatant was pooled and dried at $50{ }^{\circ} \mathrm{C}$ under vacuum. The pellet after extracting soluble sugars was boiled in $0.2 \mathrm{M} \mathrm{KOH}$ for $30 \mathrm{~min}$, adjusted to $\mathrm{pH}$ of 5.5 with $1 \mathrm{~m}$ acetic acid, then digested with 50 units of amyloglucosidase for $30 \mathrm{~min}$ at $55^{\circ} \mathrm{C}$. Sucrose, fructose, and glucose were measured spectrophotometrically as described by Jones et al. (1977). Starch was determined as glucose equivalents. The recoveries of starch, sucrose, fructose and glucose were $93 \%$ to $100 \%$ in all cases.

LEAF N AND CHL ANALYSIS. Leaf discs $\left(1 \mathrm{~cm}^{2}\right.$ in size $)$ were taken from the leaves that were used for gas exchange measurements and carbohydrate sampling to determine leaf $\mathrm{N}$ and chlorophyll. Leaf $\mathrm{N}$ was determined by the Kjeldahl method (Schuman et al., 1973). Leaf Chl was measured according to Arnon (1949).

\section{Results}

LEAF N AND CHL CONTENTS. On a leaf area basis, leaf N content increased curvilinearly as $\mathrm{N}$ supply increased (Fig. 1A). Chl content showed a similar response to N supply (Fig. 1B). There was a linear relationship between leaf $\mathrm{N}$ and Chl (Fig.1C).

$\mathrm{Co}_{2}$ ASsimilation. Over the wide range of leaf $\mathrm{N}$ content (from 1.11 to $3.01 \mathrm{~g} \cdot \mathrm{m}^{-2}$ ) examined, curvilinear relationships were found between leaf $\mathrm{N}$ and 1) light-saturated $\mathrm{CO}_{2}$ assimilation at ambient $\mathrm{CO}_{2}$ (Fig. 2A) and 2) light-saturated $\mathrm{CO}_{2}$ assimilation at saturating $\mathrm{CO}_{2}$ (Fig. 2D). Stomatal conductance at both ambient $\mathrm{CO}_{2}$ and saturating $\mathrm{CO}_{2}$ showed a similar response to leaf $\mathrm{N}$ as $\mathrm{CO}_{2}$ assimilation (Fig. 2B and E). However, the calculated intercellular $\mathrm{CO}_{2}$ concentrations decreased with increasing leaf $\mathrm{N}$ (Fig. $2 \mathrm{C}$ and $\mathrm{F}$ ).

ACTIVITIES OF KEY ENZYMES IN CALVIN CYCLE AND SUCROSE AND STARCH SYNTHESIS. On a leaf area basis, activities of key enzymes in the Calvin cycle, Rubisco, GAPDH, PRK, and those in sucrose and starch synthesis, FBPase, SPS, and AGPase increased linearly with increasing leaf $\mathrm{N}$ (Fig. 3A-F). When expressed on a leaf $\mathrm{N}$ basis, activities of Rubisco, GAPDH, and PRK increased with increasing leaf N (Fig. 3G-I), whereas activities of FBPase, SPS, and AGPase did not show significant changes (Fig. 3J-L).

Metabolite Levels. Leaf G6P, F6P, and PGA (Fig. 4A, B, and $\mathrm{D}$ ) contents increased curvilinearly with increasing leaf $\mathrm{N}$. The ratio of G6P/F6P increased as leaf $\mathrm{N}$ increased from 1.11 to $1.63 \mathrm{~g} \cdot \mathrm{m}^{-2}$, then remained constant with any further rise in leaf N (Fig. 4C).

CONCENTRATIONS OF NONSTRUCTURAL CARBOHYDRATES AT DUSK AND PREDAWN. Leaf glucose (Fig. 5A), fructose (Fig. 5B), and sucrose (Fig. 5C) contents at both predawn and dusk increased linearly with increasing leaf $\mathrm{N}$. There was no significant difference between dusk and predawn values at any given leaf $\mathrm{N}$ level. As leaf $\mathrm{N}$ increased, leaf starch content and total carbohydrate content increased linearly at dusk, but both decreased linearly at predawn (Fig. 5D and E). The export of carbon from starch breakdown during the night, calculated as the difference between dusk and predawn values, increased with increasing leaf $\mathrm{N}$ content (Fig. 5F). Total carbon export from nonstructural carbohydrates during the night also increased linearly with increasing leaf $\mathrm{N}$ content (Data not shown). 

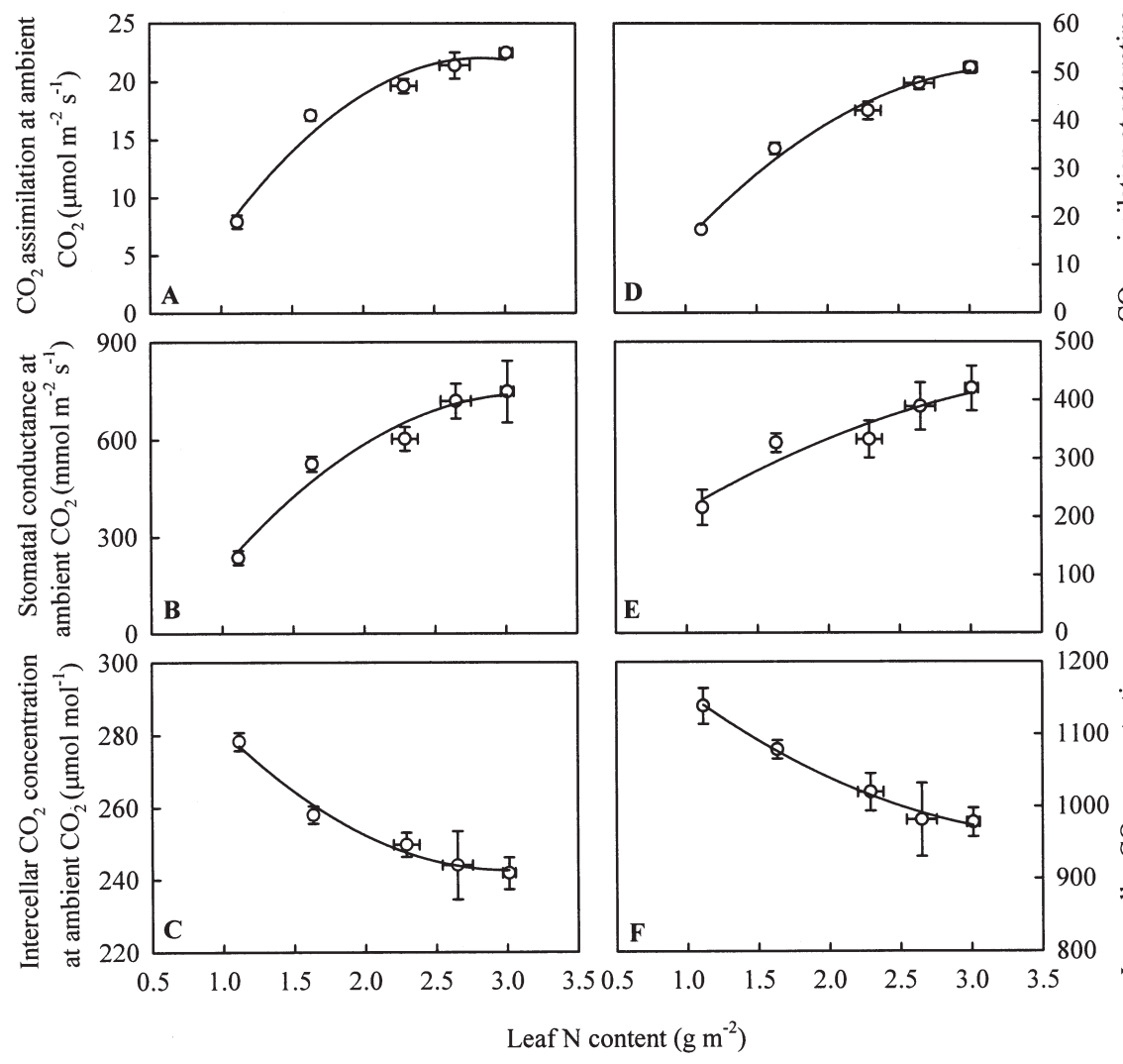

Leaf $\mathrm{N}$ content $\left(\mathrm{g} \mathrm{m}^{-2}\right)$

Fig. 2. Light-saturated $\mathrm{CO}_{2}$ assimilation (A, D), stomatal conductance (B, E), and intercellular $\mathrm{CO}_{2}$ concentration $(\mathbf{C}, \mathbf{F})$ at ambient $\mathrm{CO}_{2}\left(360 \mu \mathrm{mol} \cdot \mathrm{mol}^{-1}\right)$ and at saturating $\mathrm{CO}_{2}\left(1350 \mu \mathrm{mol} \cdot \mathrm{mol}^{-1}\right)$ in relation to $\mathrm{N}$ content in grape leaves. Each point is mean \pm standard error for the leaf $\mathrm{N}$ (horizontal) and the dependent variables (vertical) of four replications. Regression equations: (A) $\mathrm{y}=-4.5336 x^{2}+25.692 x-14.371\left(r^{2}=0.966, P<0.05\right) ;($ B $) \mathrm{y}=-115.87 x^{2}+$ $730.78 x-412.19\left(r^{2}=0.964, P<0.05\right) ;(C) \mathrm{y}=9.5332 x^{2}-57.546 x+329.34$ $\left(r^{2}=0.983, P<0.05\right) ;\left(\right.$ D) $\mathrm{y}=-6.6921 x^{2}+44.467 x-22.903\left(r^{2}=0.986, P<\right.$ $0.05) ;(\mathbf{E}) \mathrm{y}=-20.968 x^{2}+182.54 x+52.446\left(r^{2}=0.916, P=0.08\right) ;(\mathbf{F}) \mathrm{y}=$ $25.46 x^{2}-192.91 x+1323.6\left(r^{2}=0.993, P<0.01\right)$.

\section{Discussion}

Our data showed that both light-saturated $\mathrm{CO}_{2}$ assimilation at ambient and saturating $\mathrm{CO}_{2}($ Fig. 2Aand D) increased curvilinearly with increasing leaf $\mathrm{N}$. Although stomatal conductance showed a similar response to leaf $\mathrm{N}$ as $\mathrm{CO}_{2}$ assimilation (Fig. $2 \mathrm{~B}$ and $\mathrm{E}$ ), the fact that intercellular $\mathrm{CO}_{2}$ concentrations decreased with increasing leaf $\mathrm{N}$ (Fig. 2C and F) indicates that the low photosynthetic capacity of low $\mathrm{N}$ leaves is primarily determined by nonstomatal factors. These findings are similar to previous results obtained in other species where a wide range of leaf $\mathrm{N}$ has been examined (Cheng and Fuchigami, 2000; DeJong and Doyle, 1985; Evans, 1989). At low leaf $\mathrm{N}$, any increase in leaf $\mathrm{N}$ leads to a rise in $\mathrm{CO}_{2}$ assimilation. Beyond a certain point, however, $\mathrm{CO}_{2}$ assimilation does not respond to any further increase in leaf $\mathrm{N}$, indicating that leaf $\mathrm{N}$ no longer limits $\mathrm{CO}_{2}$ assimilation.

On a leaf area basis, both the key enzymes in the Calvin cycle and those in sucrose and starch synthesis increased linearly with increasing leaf $\mathrm{N}$ (Fig. 3A-F). On a leaf $\mathrm{N}$ basis, however, activities of the key enzymes in sucrose and starch synthesis remained unchanged whereas the Calvin cycle enzymes increased with increasing leaf $\mathrm{N}$ (Fig. 3G-L). This preferential increase of the Calvin cycle enzymes in response to an increasing leaf $\mathrm{N}$ may reflect an increased requirement or an excess of these enzymes under high N. $\mathrm{ACO}_{2}$ transfer resistance exists between the intercellular in high $\mathrm{N}$ leaves may be limited by end-product synthesis at a lower $\mathrm{CO}_{2}$ partial pressure than in low $\mathrm{N}$ leaves.

Leaf starch concentration at dusk increased with increasing leaf $\mathrm{N}$ in this study (Fig. 5D). This contrasts with previous data on soybean (Glycine $\max \mathrm{L}$.) at the end of the light period (Rufty et al., 1988) and tobacco at midday (Geiger et al., 1999) and $7 \mathrm{~h}$ into the photoperiod (Paul and Driscoll, 1997). Starch synthesis is regulated by AGPase. The transcript level of AGPase is increased by sugars (Müller-Röber et al., 1990). Our finding that both soluble sugars and starch at dusk increased with increasing leaf $\mathrm{N}$ is consistent with the idea that starch accumulation is a response to an increased production of sugars (Geiger et al., 1999). The elevated starch level at predawn in low $\mathrm{N}$ leaves observed in this study, however, is not due to increased starch synthesis, via sugar or nitrate-mediated regulation of AGPase found in tobacco under N limitation (Geiger et al., 1999; Scheible et al., 1997). Instead, it is the result of decreased export of carbon from starch degradation during the night. If the carbon export from starch degradation during the night is indicative of the sink activity, this indicates that the demand for carbohydrates decreases, relative to carbon supply, in response to $\mathrm{N}$ limitation.

Excessive starch accumulation is thought to hinder $\mathrm{CO}_{2}$ diffusion within the mesophyll cells (Nafziger and Koller, 1976) and physically distort the structure of chloroplast (Cave et al., 1981; DeLucia et al., 1985). Although leaf starch content at predawn increased linearly with decreasing leaf $\mathrm{N}$ in this experiment (Fig. 5D), the starch content in leaves with the lowest $\mathrm{N}$ was only $1.66 \%$ on a dry weight basis. This is much lower than that observed in other species at which $\mathrm{CO}_{2}$ assimilation may be affected (DeLucia et al., 1985; Nafziger and Koller, 1976; Potter and Breen, 1980). Starch accumulation at this level would be too low to hinder $\mathrm{CO}_{2}$ diffusion or to disrupt chloroplasts. Therefore, the elevated starch level at predawn observed in this study would not have any direct effect on $\mathrm{CO}_{2}$ assimilation in low $\mathrm{N}$ leaves. 
Leaf glucose, fructose, and sucrose content at predawn and at dusk increased linearly with increasing leaf $\mathrm{N}$ (Fig. 5A-C). Sucrose content of rice leaves (Nakano et al., 1997) before nighttime and glucose content in bean leaves (Jifon and Wolfe, 2002) in the mid-afternoon increased as $\mathrm{N}$ supply increased. Harmens et al. (2000) also found that Dactylis glomerata plants grown at the lowest external nitrate supply had the lowest soluble carbohydrate concentration in leaves. Our result, however, contrasts with previous findings that $\mathrm{N}$ limitation leads to the accumulation of soluble
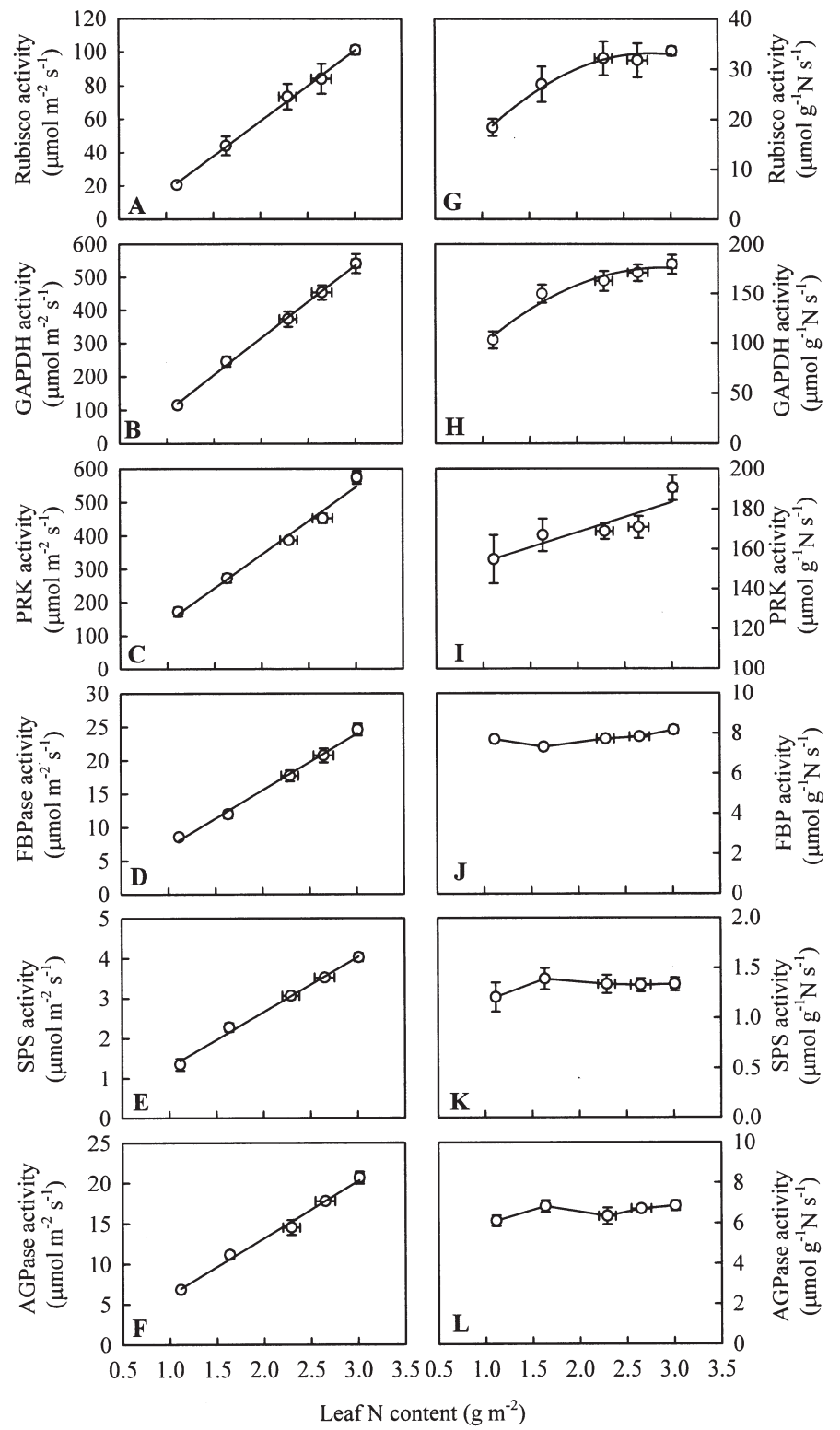

Fig. 3. Activities of ribulose-1,5-bisphosphate carboxylase/oxygenase (Rubisco, A and G), NADP-glyceraldehyde-3-phosphate dehydrogenase (GAPDH, B and $\mathbf{H}$ ), phosphoribulokinase (PRK, $\mathbf{C}$ and $\mathbf{I}$ ), fructose-1,6-bisphosphatase (FBPase, D and $\mathbf{J}$ ), sucrose phosphate synthase (SPS, $\mathbf{E}$ and $\mathbf{K}$ ), and ADPglucose pyrophosphorylase (AGPase, $\mathbf{F}$ and $\mathbf{L}$ ), expressed on leaf area or leaf $\mathrm{N}$ basis, in relation to $\mathrm{N}$ content in grape leaves. Each point is mean \pm standard error for the leaf $\mathrm{N}$ (horizontal) and the dependent variables (vertical) of four replications. Regression equations: $(\mathbf{A}) \mathrm{y}=41.942 x-25.055\left(r^{2}=0.997, P<\right.$ $0.01) ;($ B $) \mathrm{y}=219.89 x-125.16\left(r^{2}=0.998, P<0.01\right) ;(\mathbf{C}) \mathrm{y}=201.7 x-59.792$ $\left(r^{2}=0.985, P<0.01\right) ;(\mathbf{D}) \mathrm{y}=8.4309 x-1.3269\left(r^{2}=0.994, P<0.01\right) ;(\mathbf{E}) \mathrm{y}=$ $1.3745 x-0.0985\left(r^{2}=0.994, P<0.01\right) ;(\mathbf{F}) \mathrm{y}=7.0531 x-0.9265\left(r^{2}=0.992\right.$ $P<0.01) ;(\mathbf{G}) \mathrm{y}=-5.1159 x^{2}+28.513 x-6.5992\left(r^{2}=0.981, P<0.05\right) ;(\mathbf{H})$ $\mathrm{y}=-21.189 x^{2}+123.82 x-4.6748\left(r^{2}=0.961, P<0.05\right) ;($ I) $\mathrm{y}=14.976 x+$ $138.416\left(r^{2}=0.80, P<0.05\right)$. sugars in leaves (Logan et al., 1999; Paul and Driscoll, 1997). High concentrations of soluble sugars, particularly hexoses, repress the expression of genes that encode photosynthetic enzymes, such as Rubisco (Koch, 1996; Krapp et al., 1993; Sheen, 1990). The lack of accumulation of soluble sugars in this study, therefore, indicates that the feedback suppression mechanism via accumulation of soluble carbohydrates does not play a significant role in determining the activities of the key enzymes and the rate of $\mathrm{CO}_{2}$ assimilation in grape leaves under $\mathrm{N}$ limitation. Chaumont et al (1994) also found that fruit removal did not cause accumulation of sucrose or starch in leaves of Vitis vinifera and there was no correlation between leaf sucrose content and the decrease of $\mathrm{CO}_{2}$ assimilation after mid-morning on a daily basis.

In addition to repressing the expression of photosynthetic genes, accumulation of soluble sugars may lead to characteristic changes
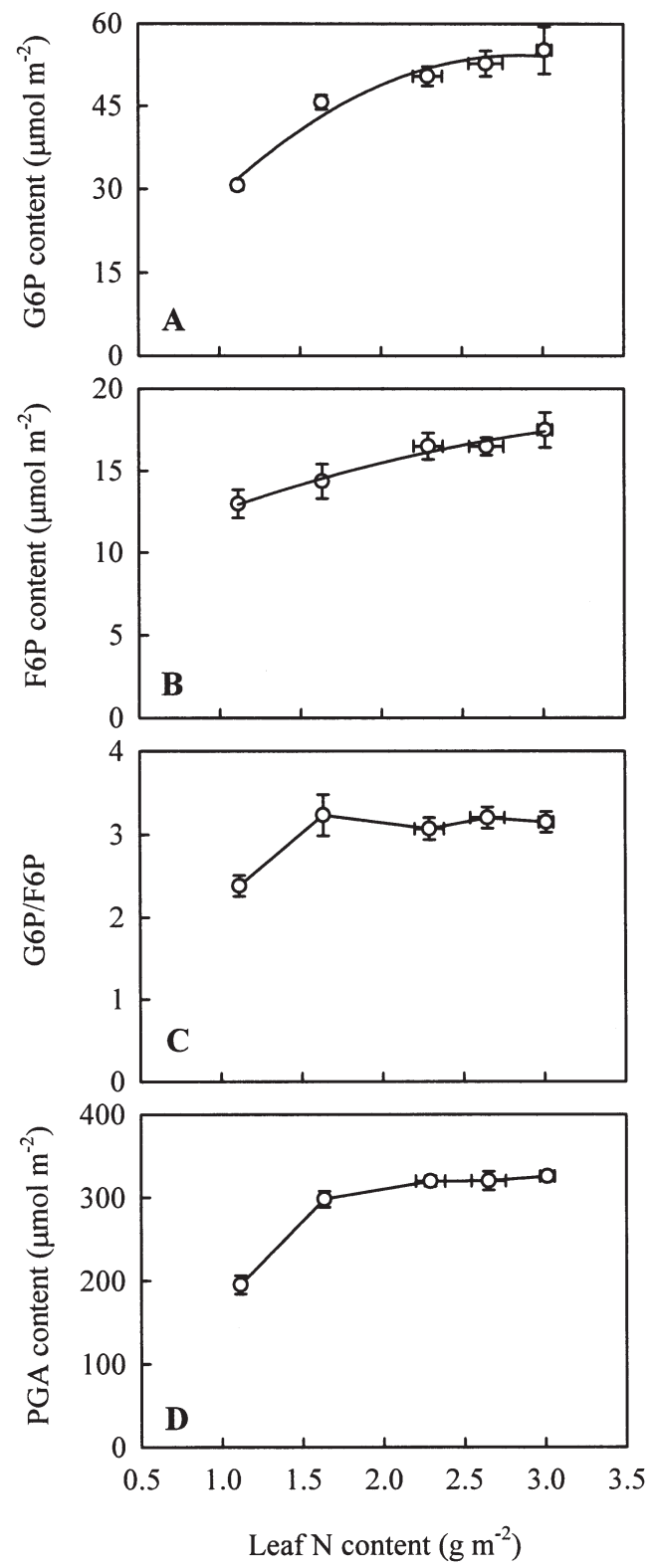

Fig. 4. Glucose-6-phosphate (G6P) content (A), fructose-6-phosphate (F6P) content (B), G6P/F6P (C), and 3-phosphoglycerate (PGA) content (D) in relation to $\mathrm{N}$ content of grape leaves. Each point is mean \pm standard error for the leaf $\mathrm{N}$ (horizontal) and the dependent variables (vertical) of four replications. Regression equations: (A) y $=-7.3367 x^{2}+42.016 x-5.9099\left(r^{2}=0.968, P<0.05\right) ;($ B $) \mathrm{y}$ $=-0.5051 x^{2}+4.4291 x+8.6448\left(r^{2}=0.978, P<0.05\right)$. 

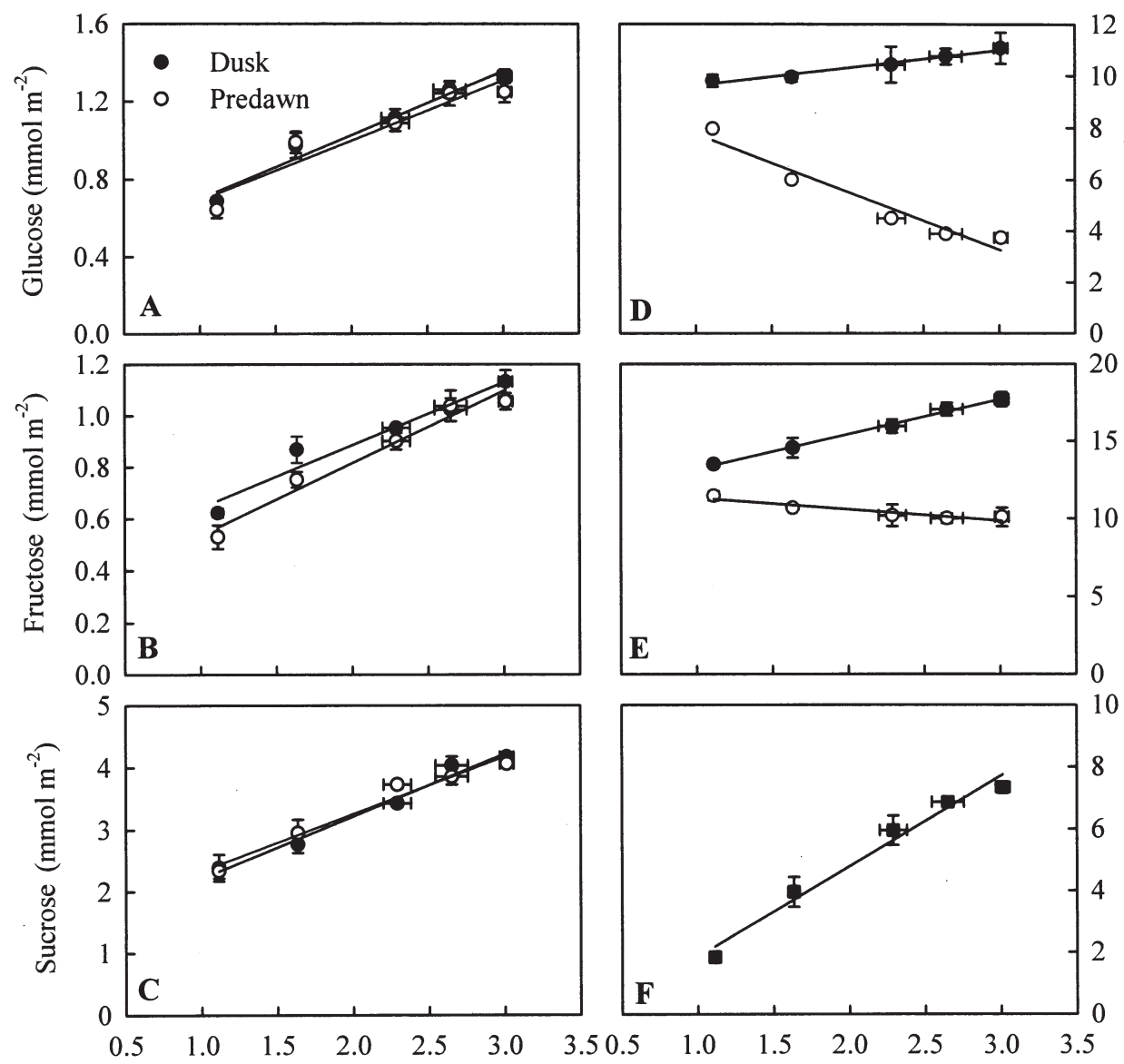

Leaf $\mathrm{N}$ content $\left(\mathrm{g} \mathrm{m}^{-2}\right)$

Fig. 5. Glucose (A), fructose (B), sucrose (C), starch (B), total nonstructural carbohydrate $(\mathbf{E})$ contents at predawn and at dusk, and carbon export from starch degradation during the night $(\mathbf{F})$ in relation to $\mathrm{N}$ content of grape leaves. Each point is mean \pm standard error for the leaf $\mathrm{N}$ (horizontal) and the dependent variables (vertical) of four replications. Regression equations for glucose at predawn: $\mathrm{y}=0.3078 x+0.3829\left(r^{2}=0.905, P<0.01\right)$, and at dusk: $\mathrm{y}=0.3275 x$ $+0.3717\left(r^{2}=0.968, P<0.01\right)$; for fructose at predawn: $\mathrm{y}=0.2808 x+0.2544$ $\left(r^{2}=0.967, P<0.01\right)$ and at dusk: $\mathrm{y}=0.2435 x+0.3989\left(r^{2}=0.947, P<0.01\right) ;$ for sucrose at predawn: $\mathrm{y}=0.9221 x+1.4104\left(r^{2}=0.967, P<0.01\right)$ and at dusk: $\mathrm{y}=1.0021 x+1.2115\left(r^{2}=0.980, P<0.01\right)$; for starch at predawn: $\mathrm{y}=-2.2422 x$ $+10.007\left(r^{2}=0.941, P<0.01\right)$ and at dusk: $\mathrm{y}=0.6895 x+8.9228\left(r^{2}=0.971, P\right.$ $<0.01)$; for total carbohydrates at predawn: $\mathrm{y}=-0.7315 x+12.055\left(r^{2}=0.869\right.$, $P<0.05)$ and at dusk: $\mathrm{y}=2.2649 x+10.907\left(r^{2}=0.996, P<0.01\right)$; for starch export during the night: $\mathrm{y}=0.6895 x+8.9228\left(r^{2}=0.971, P<0.01\right)$.

in metabolite levels. Under feedback conditions, phosphorylated intermediates accumulate at the expense of inorganic phosphate (Sharkey and Vanderveer, 1989); PGA increases to upregulate starch synthesis (Krapp and Stitt, 1995). However, we found that PGA, G6P, and F6P contents increased curvilinearly with increasing leaf $\mathrm{N}$ (Fig. 4A, B, and D) and the ratio of G6P/F6P was lowest in leaves with the lowest $\mathrm{N}$ (Fig. 4C). In contrast, Paul and Driscoll (1997) found that N-deficient tobacco plants had higher concentrations of G6P and F6P, and a higher G6P/F6P ratio, with small effects on PGA. Our metabolite data further indicate that the reduction of $\mathrm{CO}_{2}$ assimilation in $\mathrm{N}$-limited grape leaves is not caused by feedback repression of photosynthesis via sugar accumulation.

In summary, there was a curvilinear relationship between leaf $\mathrm{N}$ and $\mathrm{CO}_{2}$ assimilation whereas the key enzymes in photosynthesis increased linearly with increasing $\mathrm{N}$ in grape leaves. At very high leaf $\mathrm{N}$, a decrease in leaf $\mathrm{N}$ resulted in a decrease in
20
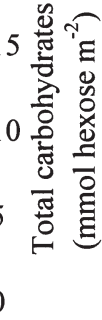

the key enzymes in photosynthesis, but did not cause a decrease in $\mathrm{CO}_{2}$ assimilation. This suggests that these enzymes are in excess of that required for photosynthesis. However, below a certain leaf $\mathrm{N}$ level, any further decrease led to decreases in both the enzymes and $\mathrm{CO}_{2}$ assimilation. The reduction in key enzymes and the rate of $\mathrm{CO}_{2}$ assimilation under $\mathrm{N}$ limitation were not accompanied by accumulation of soluble sugars or characteristic changes of metabolites indicative of feedback repression. These data support the conclusion that the reduced capacity of $\mathrm{CO}_{2}$ assimilation in $\mathrm{N}$-limited grape leaves is caused by the coordinated decreases in the activities of key enzymes involved in $\mathrm{CO}_{2}$ assimilation as a result of direct $\mathrm{N}$ limitation, not by the indirect feedback suppression of $\mathrm{CO}_{2}$ assimilation, via sugar accumulation.

\section{Literature Cited}

Arnon, D.I. 1949. Copper enzymes in isolated chloroplasts. Polyphenoloxidase in Beta vulgaris. Plant Physiol. 24:1-15.

Cave, G., T.C. Tolley, and B.R. Strain. 1981. Effect of carbon dioxide enrichment on chlorophyll content, starch content and starch grain structure in Trifolium subteraneum leaves. Physiol. Plant. 51:171-174.

Chaumont M., J.F. Morot-Gaudry, and C.H. Foyer. 1994. Seasonal and diurnal changes in photosynthesis and carbon partitioning in Vitis vinifera leaves in vines with and without fruit. J. Expt. Bot. 45: 1235-1243.

Chen L.-S., Q. Lin, and A. Nose. 2002. A comparative study on diurnal changes in metabolite levels in the leaves of three crassulacean acid metabolism (CAM) species, Ananas comosus, Kalanchoë daigremontiana and $K$. pinnata. J. Expt. Bot. 53:341-350.

Cheng L. and F.H. Fuchigami. 2000. Rubisco activation state decreases with increasing nitrogen content in apple leaves. J. Expt. Bot. 51: 1687-1694.

DeJong T.M. and J.F. Doyle. 1985. Seasonal relationships between leaf nitrogen content (photosynthetic capacity) and leaf canopy light exposure in peach (Prunus persica). Plant Cell Environ. 8:701-706.

DeLucia E.H., T.W. Sasek, and B.R. Strain. 1985. Photosynthetic inhibition after long-term exposure to elevated levels of atmospheric carbon dioxide. Photosyn. Res. 7:175-184.

Evans J.R. 1983. Nitrogen and photosynthesis in the flag leaf of wheat (Triticum aestivum L.). Plant Physiol. 72:297-302.

Evans J.R. 1989. Photosynthesis and nitrogen relationships in leaves of $\mathrm{C}_{3}$ plants. Oecologia 78:9-19.

Geiger M., V. Haake, F. Ludewig, U. Sonnewald, and M. Stitt. 1999. The nitrate and ammonium nitrate supply have a major influence on the responses of photosynthesis, carbon metabolism, nitrogen metabolism and growth to elevated carbon dioxide in tobacco. Plant Cell Environ. 22:1177-1199.

Grof C.P.L., D.P. Knight, S.D. McNeil, J.E. Lunn, and J.A. Campbell. 1998. A modified assay method shows leaf sucrose-phosphate synthase activity is correlated with leaf sucrose content across a range of sugarcane varieties. Austral. J. Plant Physiol. 25:499-502. 
Harmens H., C.M. Stirling, C. Marshall, and J.F. Farrar. 2000. Does down-regulation of photosynthetic capacity by elevated $\mathrm{CO}_{2}$ depend on N supply in Dactylis glomerata? Physiol. Plant. 108:43-50.

Jang J.-C. and J. Sheen. 1994. Sugar sensing in higher plants. Plant Cell 6:1665-1679.

Jifon J.L. and D.W. Wolfe. 2002. Photosynthetic acclimation to elevated $\mathrm{CO}_{2}$ in Phaseolus vulgaris L. is altered by growth response to nitrogen supply. Global Change Biol. 8:1018-1027.

Jones M.G.K., W.J. Outlaw, and O.H. Lowery. 1977. Enzymic assay of $10^{-7}$ to $10^{-14}$ moles of sucrose in plant tissues. Plant Physiol. 60: 379-383.

Kerr P.S., S.C. Huber, and D.W. Israel. 1984. Effect of N-source on leaf sucrose phosphate synthase, starch formation and whole plant growth. Plant Physiol. 75:483-488.

Koch K.E. 1996. Carbohydrate-modulated gene expression in plants. Annu. Rev. Plant Physiol. Plant Mol. Biol. 47:509-540.

Krapp A., B. Hofmann, C. Schäffer, and M. Stitt. 1993. Regulation of the expression of $r b c S$ and the other photosynthetic genes by carbohydrates: A mechanism of the sink regulation of photosynthesis? Plant J. 3:817-828.

Krapp A. and M. Stitt. 1995. An evaluation of direct and indirect mechanisms for the sink-regulation of photosynthesis in spinach: Changes in gas exchange, carbohydrates, metabolites, enzyme activities and steady-state transcript levels after cold-girdling source leaves. Planta 195:313-323.

Leegood R.C. 1990. Enzymes of the Calvin cycle, p. 15-37. In: P.J. Lea (ed.). Methods in plant biochemistry. vol. 3. Academic Press, New York.

Logan B.A., B. Demmig-Adams, T.N. Rosenstiel, and W.W. Adams, III. 1999. Effects of nitrogen limitation on foliar antioxidants in relationship to other metabolic characteristics. Planta 209:213-220.

Makino A., H. Nakano, and T. Mae. 1994. Responses of ribulose-1,5phosphate carboxylase, cytochrome $f$, and sucrose synthesis enzymes in rice leaves to leaf nitrogen and their relationships to photosynthesis. Plant Physiol. 105:173-179.

Martin T., O. Oswald, and I.A. Graham. 2002, Arabidopsis seedling growth, storage mobilization, and photosynthetic gene expression are regulated by carbon : nitrogen availability. Plant Physiol. 128: 472-481.

Müller-Röber B.T., J. Komann, L.C. Hannah, L. Willmitzer, and U. Sonnewald. 1990. One of two different ADP glucose pyrophosphorylase genes from potato responds strongly to elevated levels of sucrose. Mol. Gen. Genet. 224:136-146.

Nafziger E.D. and H.R. Koller. 1976. Influence of leaf starch concentration on $\mathrm{CO}_{2}$ assimilation in soybean. Plant Physiol. 57:560-563.

Nakano H., A. Makino, and T. Mae. 1997. The effect of elevated partial pressures of $\mathrm{CO}_{2}$ on the relationship between photosynthetic capacity and $\mathrm{N}$ content in rice leaves. Plant Physiol. 115:191-198.

Nielsen TH.,A. Krapp, U. Röper-Schwarz, and M. Stitt. 1998. The sugarmediated regulation of genes encoding the small subunit of Rubisco and the regulatory subunit of ADP glucose pyrophoshorylase is modified by phosphate and nitrogen. Plant Cell Environ. 21:443-454.

Paul M.J. and S.P. Driscoll. 1997. Sugar repression of photosynthesis: the role of carbohydrates in signaling nitrogen deficiency through source: sink imbalance. Plant Cell Environ. 20:110-116.

Paul M.J. and T.K. Pellny. 2003. Carbon metabolite feedback regulation of leaf photosynthesis and development. J. Expt. Bot. 54:539-547.

Potter J.R. and P.J. Breen. 1980. Maintenance of high photosynthetic rates during the accumulation of high leaf starch levels in sunflower and soybean. Plant Physiol. 66:528-531.

Radoglou K.M. and P.G. Jarvis. 1992. The effects of $\mathrm{CO}_{2}$ enrichment and nutrient supply on growth morphology and anatomy of Phaseolus vulgaris L. seedlings. Ann. Bot. 70:245-256.

Robinson J.M. and C. Baysdorfer. 1985. Interrelationships between carbon and nitrogen metabolism in mature soybean leaves and isolated mesophyll cells, p. 333-357. In: R.L. Health and J. Preiss (eds.). Regulation of carbon partitioning in photosynthetic tissue. Amer. Soc. Plant Physiol., Rockville, Md.

Rufty, Jr., T.W., S.C. Huber, and R.J. Volk. 1988. Alteration in leaf carbohydrate metabolism in responses to nitrogen stress. Plant Physiol. 88:725-730.

Sage R.F., T.D. Sharkey, and J.R. Seemann. 1990. Regulation of ribulose1,5-bisphosphate carboxylase activity in response to light intensity and $\mathrm{CO}_{2}$ in the $\mathrm{C}_{3}$ annuals Chenopodium album L. and Phaseolus vulgaris L. Plant Physiol. 94:1735-1742.

Scheible W.-R., A. González-Fontes, M. Lauerer, B. Müller-Röber, M. Caboche, and M. Stitt. 1997. Nitrate acts as a signal to induce organic acid metabolism and repress starch metabolism in tobacco. Plant Cell 9:783-796.

Schuman G.E., A.M. Stanley, and D. Knudsen. 1973. Automated total nitrogen analysis of soil and plant samples. Proc. Soil Sci. Soc. Amer. 37:480-481.

Sharkey T.D. 1990. Feedback limitation of photosynthesis and the physiological role of ribulose bisphosphate carboxylase carbamylation. Bot. Mag. Tokyo Spec. Issue 2:87-105.

Sharkey T.D. and P.J. Vanderveer. 1989. Stromal phosphate concentration is low during feedback limited photosynthesis. Plant Physiol. 91: 679-684.

Sheen J. 1990. Metabolic repression of transcription in higher plants. Plant Cell 2:1027-1038.

SmithA.M., M. Bettey, and I.D. Bedford. 1989. Evidence that the $r b$ locus alters the starch content of developing pea embryos through an effect on ADP glucose pyrophosphorylase. Plant Physiol. 89:1279-1284.

Stitt M. 1986. Limitation of photosynthesis by carbon metabolism. I. Evidence for excess electron transport capacity in leaves carrying out photosynthesis in saturating light and $\mathrm{CO}_{2}$. Plant Physiol. 81:1115-1122.

Usuda H. 1985. Changes in levels of intermediates of the $C_{4}$ cycle and reductive pentose phosphate pathway during induction of photosynthesis in maize leaves. Plant Physiol. 78:859-864.

von Caemmerer S. and J.R. Evans. 1991. Determination of the average partial pressure of $\mathrm{CO}_{2}$ in chloroplasts from leaves of several $\mathrm{C}_{3}$ species. Austral. J. Plant Physiol. 18:287-305. 